\title{
Article \\ Hostile Immigration Policy and the Limits of Sanctuary as Resistance: Counter-Conduct as Constructive Critique
}

\author{
Cathy A. Wilcock \\ International Institute of Social Studies, Erasmus University Rotterdam, 2518 AX The Hague, The Netherlands; \\ E-Mail:wilcock@iss.nl
}

Submitted: 12 July 2019 | Accepted: 29 August 2019 | Published: 28 November 2019

\begin{abstract}
This article addresses the tense relationship between national and municipal approaches to the inclusion and exclusion of irregular immigrant 'non-citizens.' While national policies in the UK have created hostility for irregular migrants, municipallevel cities of sanctuary offer a 'warm welcome' which has been extolled as immanently progressive in the face of hostility. This article assesses the extent to which city-based sanctuary movements in the UK provide effective resistance to the national policies of hostility. Building on critiques of the City of Sanctuary (CoS) movement, effective resistance is redefined using a Foucauldian counter-conduct approach. Through applying a counter-conduct lens to a document analysis of the CoS newsletter archive and online resources, the article shows it is not easy to dismiss sanctuary as ineffective resistance, as some earlier critiques have argued. Rather, $\operatorname{CoS}$ is demonstrated as both effective and ineffective counter-conduct due to its uneven approach to the various discourses within the hostile environment.
\end{abstract}

\section{Keywords}

cities of sanctuary; counter-conduct; hostile environment; UK immigration policy

\section{Issue}

This article is part of the issue "Inclusion through Enacted Citizenship in Urban Spaces" edited by Rachel Kurian (Erasmus University Rotterdam, The Netherlands) and Helen Hintjens (Erasmus University Rotterdam, The Netherlands)

(C) 2019 by the author; licensee Cogitatio (Lisbon, Portugal). This article is licensed under a Creative Commons Attribution 4.0 International License (CC BY).

\section{Introduction}

This article addresses the relationship between national and municipal approaches to the inclusion and exclusion of irregular immigrant 'non-citizens.' It speaks to conceptualisations of citizenship which see beyond formalised citizenship 'status' and describe instead a tacit 'right to presence': the conditions for which are collectively instantiated-or enacted-by a political community (Isin, 2013). Using this conceptualisation of citizenship, multiple conditions for inclusion are performed and competed for by various actors. Inspired by Lefebvre's Right to the City (1968), several scholars have focused on urban space as a site where national modes of exclusivity can be 'ruptured' or 'threatened' (Bauder, 2016; Harvey, 2003; Purcell, 2002). While the state dictates who is entitled to legal 'rights,' the 'right of presence' for belonging to the urban political community is the province of the city and its inhabitants. This article addresses how municipal-level actors resist the conditions for exclusion and inclusion which they inherit from the state. It does so through a document analysis of the UK's national immigration policy-termed the 'hostile environment' - and the City of Sanctuary (CoS) movement which is embedded within local council infrastructure. As will be shown, the UK national immigration policy promotes substantive citizenship whereby the 'right of presence' is reserved for some and denied to others based on the false distinction between morally corrupt irregular migrants and morally pure regular migrants. Against this, urban actors in $\mathrm{CoS}$ enact competing conditions for inclusion based on hospitality.

First, the article outlines the details of 'hostile environment' policy-making and the responses from the $\mathrm{CoS}$ movement. It then demonstrates that critiques of $\mathrm{CoS}$ have concluded that, overall, it fails to resist hostil- 
ity. Seeking to offer a more constructive critique, I argue for the reimagining of resistance as Foucauldian counterconduct. Drawing on the heuristic model developed by Death $(2010,2016)$ and examples of successful counterconduct from various contexts, the article then discusses to what extent $\operatorname{CoS}$ is successful counter-conduct to the hostile environment. It draws evidence from an archive of $\operatorname{CoS}$ documentation and media reports. Specifically, the article engages with $\mathrm{CoS}$ newsletters from the period August 2018-August 2019 as well as handbooks, charters, annual reports and online resources available on cityofsanctuary.com. In addition, media reports between 2010-2019 and secondary academic sources contribute to illustrative exemplification. I also write with ten years' experience of participating in the UK migrant and refugee rights sector in a voluntary capacity, engaging with-but not formally a member of-CoS.

\section{The Hostile Environment}

The 'hostile environment' has come to describe the UK's policy approach to immigration (Webber, 2019). In its broadest sense, it refers to the gradual introduction of selectively restrictive policies most significantly under New Labour in the late 1990s (Lewis, Waite, \& Hodkinson, 2017, p. 189; Mulvey, 2011) but it can also be traced back to the 1970s (Bowling \& Westenra, 2018, p. 2; YuvalDavis, Wemyss, \& Cassidy, 2018, p. 233). In its narrow sense, the hostile environment describes the rhetorical and legislative platform of the Conservative/Liberal coalition and Conservative government (2010-current). Two Immigration Acts (2014 and 2016) were introduced by then home secretary Theresa May who stated that they should create a 'hostile environment' for migrants (Kirkup, 2012). While often credited with coining the phrase, May borrowed the term from Labour Home Secretary Alan Johnson who first used it in relation to immigration policy in 2009 (Taylor, 2018, p. 2). Much of the content of the Acts was devised by the "Hostile Environment Working Group" established to concoct policies which would 'make immigrants' lives more difficult' (Aitkenhead, 2013; Webber, 2019, p. 77). While the hostile environment was disowned following the 2018 Windrush scandal by then home secretary Sajid Javid, no legislative changes have been implemented (Grierson, Farrer, \& Sparrow, 2018). Critics maintain that the UK still pursues a modus operandi of fervent hostility (Webber, 2018).

The 2014 and 2016 Acts enshrined specific efforts to police irregular migrants, of which there were an estimated 800,000 living in the UK (York, 2015, p. 228). Migration status can become irregularised in a number of ways: People can enter the UK clandestinely or fraudulently, they can overstay their visas or violate the terms of their visas, and they can have their asylum claims rejected but avoid deportation (Finch \& Cherti, 2011; Papademetriou, 2005). Trafficking victims can also become irregular migrants upon entry into the UK. The stated aim of the hostile environment was to implement the 'four Ds of deterrence' on irregular migrants: dispersal, detention, destitution, and deportation (Webber, 2004). According to May, this introduced a push factor which would overwrite the pull of previous excessively lenient immigration regimes (House of Commons, 2015). Ironically, the justification for these Acts, described in the Conservative manifesto, was to meet the arbitrary target of reducing net immigration to the tens not hundreds of thousands (The Conservative Party, 2015, p. 29). Since irregular immigrants are-by definition-absent from official statistics, the justification is entirely spurious. This marks the hostile environment as an example of 'symbolic policy making' (Weisz, 2018, p. 12) which is designed to appease agitated voters and has no basis in rational analysis. The policing of those with irregular status can therefore be seen, not as a means to meet immigration targets, but as an assertion of state control over substantive citizenship, or the 'right of presence.'

The 2014 and 2016 Acts were characterised by two main contributions: first, 'everyday bordering' (YuvalDavis et al., 2018) or the expansion and internalisation of border checking into 'quotidian life' (Lewis et al., 2017, p. 190) and second, the removal of rights for asylumseekers. The 'insourcing' of border control (Menjivar, 2014) involves serving fines or imprisonment to employers who hire irregular immigrants and to landlords, banks, and the Driver Vehicle Licensing Agency when it has been found that they have provided their goods and services to irregular migrants (Immigration Act, 2014, c. 3, s. 33-47; Immigration Act, 2016, c. 2). The Acts also removed rights for asylum-seekers, specifically to appeal decisions on their cases (Immigration Act, 2014, c. 2; Immigration Act, 2016, c. 4) and empowered immigration officers to detain and electronically tag asylumseekers in the appeals process (Immigration Act, 2014, c. 1 , s. 4 ; Immigration Act, 2016, c. 3). These measures built on previous Acts legally requiring public servants such as doctors, teachers, social workers, marriage registrars and university professors to check and report the status of their patients, clients, students, etc. or face fines and imprisonment (Immigration and Asylum Act, 1999; Nationality, Immigration and Asylum Act, 2002, c. 6 , s. 129-133). Asylum-seekers already had their right to work denied in 2002 (Nationality, Immigration and Asylum Act, 2002, c. 6) and their right to non-emergency health care and free English language classes withdrawn in 2006 (Yuval-Davis et al., 2018, p. 233). The 2014 and 2016 Acts extended these hostilities through creating information sharing pathways between the Home Office and social and health services (Immigration Act, 2016, c. 3, s. 55) and ensured the enforcement of penalties enshrined in earlier Acts.

\section{Cities of Sanctuary}

Various forms of local-level resistance have undermined this national hostility including collective noncompliance among doctors, teachers and social work- 
ers (Kmietowicz, 2018; Skinner \& Salhab, 2019). The Safe Surgeries campaign backed by \#peoplenotpassports asks General Practitioners to stop sharing patient data with the Home Office (Saadi \& McKee, 2018). Following successful campaigning by Migrant Rights Network, the Memorandum of Understanding between NHS Digital and the Home Office has been scrapped during the time of writing this article. In addition, lobbying groups such as "Still Human Still Here" and "No Recourse to Public Funds" argue for the re-establishment of rights for failed asylum-seekers.

The most institutionalised form of resistance is the CoS movement. It represents the largest consolidated effort among municipal governments and local councils to counteract the directives of the state. CoS originated in the USA out of a multi-faith movement of churches and synagogues which had historically sought to subvert national policy on issues such as slavery and civil rights (Bauder, 2017; Critchley \& Trembly, 2017). Taking inspiration from such movements and institutionalising that resistance within the local council infrastructure, the first UK cities of sanctuary were announced in Sheffield and Swansea in 2005 (Darling, Barnett, \& Eldridge, 2010, p. 46) and in 2019 there are 113 officially recognised cities and places of sanctuary in the UK.

While cities of sanctuary operate independently, in order to attain official status from the CoS network, they must: a) show they are committed to the key goals of the movement; and b) receive the backing of their local city council (Darling et al., 2010, p. 47). The key goals, outlined in the City of Sanctuary handbook (Barnett \& Bhogal, 2009) and the CoS Charter (City of Sanctuary, 2017, p. 3) are 'to build a culture of hospitality for people seeking sanctuary in the UK' and to 'influence policymakers and public attitudes throughout the country.' As the national co-ordinator states, $\operatorname{CoS}$ aims 'to dispel misconceptions and build a culture of hospitality' (Salman, 2008, p. 2). These goals are achieved through creating 'opportunities for relationships of friendship and solidarity' (City of Sanctuary, 2017, p. 3) between those 'with and without status' (Barnett \& Bhogal, 2009, p. 83). Typical CoS activities involve storytelling nights, boardgame evenings, blogging workshops, community gardening, conversation clubs and the facilitation of school visits and training workshops for public service providers. In addition, CoS grants Sanctuary awards to various establishments-schools, museums, theatres, and even cafés - to recognise their commitment to hospitality towards migrants. All activities have an underlying commitment to offering a 'positive message of welcome' to immigrants of all kinds and to transforming the ways in which migrants are perceived by local populations (City of Sanctuary, 2019, p. 2).

\section{The Limits of Hospitality as Resistance to Hostility}

Proponents claim that the sanctuary movement is a 'much needed and healthy antidote to the creeping crim- inalisation of migration' (Hintjens \& Pouri, 2014, p. 224). Many commentators have found the movement immanently progressive in the dark national context. Bauder and Gonzalez (2018) argue that CoS represents the reframing of belonging at the urban, rather than the national level. In the face of national exclusivity, the city is 'reimagined as an inclusive space' (Bauder \& Gonzalez, 2018, p. 125). Darling et al. (2010, p. 47) quote a Georgian refugee in Sheffield who said:

It's brilliant work. It's bringing together locals and foreigners and saying: Look, we're human beings and we can live together, we have a lot to share and we can work together to make our city a better place for all of us.

Through answering hostility with hospitality, CoS clearly 'troubles assumptions about who does and who does not have the right to be present in the city' (Squire, 2011, p. 298). It encourages 'minor acts of citizenship' in everyday contexts which 'momentarily disrupt' the social hierarchies imposed by the state (Squire, 2011, p. 304). If the question is whether or not the sanctuary movement has done any social good, the answer is yes, demonstrably.

However, while being a social remedy to hostility, the extent to which CoS can resist the hostile environment has been seriously questioned. CoS organisations are almost always established and run by non-vulnerable members of communities: those who are neither seeking asylum nor with irregular status (Hintjens \& Pouri, 2014, p. 223). Activism led by undocumented migrants has constituted a form of insurgent citizenship where belonging is actively claimed by the excluded, with or without a spirit of welcome from those on the inside (Swerts, 2017). Concerns have been raised that CoS could overshadow the nascent insurgent politics originating with the highly agential and capable-but often infantilized-irregular immigrant population. This has even been recognised by $\mathrm{CoS}$, and their Strategic Objective One in their 2018 annual report is to 'improve the engagement and participation of people seeking sanctuary' (City of Sanctuary, 2019, p. 2).

The most incisive critique of the CoS movement has been made against their wilfully apolitical stance. Early critiques claimed that 'City of Sanctuary explicitly avoids political lobbying or campaigning in favour of a more subtle process of transforming culture' (Squire, 2011, p. 296). Since then, CoS has recently initiated a political campaigning sphere of activity: For example, they spearheaded the 'Lift the Ban' campaign in 2018 which asked for asylum-seekers to have the rights to work, to family reunification and a time-limited detention. Their campaigning, however, does not recommend tactics beyond letter-writing and petitioning and does not extend to the protection of other criminalised migrant groups, for example, the exploitation of undocumented workers. Their apolitical stance also extends to individual asylum cases. As Bagelman (2013) has observed, CoS organisations 
place their emphasis on the experience of waiting for Home Office decisions. During this time of waiting, sanctuary cities go to lengths to make people feel welcome, comfortable and distracted. In doing so, they contribute to the 'normalisation' or 'domestication' of being held in limbo (Bagelman, 2013, p. 55). In cases where the status of an individual becomes genuinely irregularised-when their claim or appeal is rejected-CoS does not offer support to challenge or campaign against such decisions, even when asylum claimants believe the Home Office has acted unfairly or incompetently. While they have supported isolated anti-deportation campaigns (see, for example, BBC, 2019), they have not protested against the 'voluntary assisted return' policy where asylum charities are given government funding to advise failed asylumseekers to self-deport.

As such, some service users have observed that when a $\operatorname{CoS}$ is unveiled, there is 'a lot of noise, some newspaper articles, but nothing really change[s]' (Hintjens \& Pouri, 2014, p. 223). Without rights to participate in society independently, being made to 'feel welcome' is somewhat insufficient for many of those without status. In other words, CoS pursues a 'be welcome while you wait' agenda which is institutionally cautious about questioning the ever-diminishing rights available during the wait, and when the wait is over. In this way, Bagelman (2013, p. 49) argues that the seemingly hospitable City of Sanctuary in fact contributes to a hostile asylum regime' and the relations of injustice produced by the hostile environment are perpetuated rather than resolved by the sanctuary movement (Squire \& Darling, 2013, p. 60).

\section{Reimagining Resistance as Counter-Conduct}

While sharing the above frustrations, I question the utility of this critique for a movement which is enacting resistance from within a formal local council political infrastructure. The bar is very high for what counts as resistance in the above critique. To satisfy their critics, CoS would have to commit fully to radical political tactics, anti-deportation campaigning and begin engaging with 'illegalised' factions of undocumented migrants. This would entail CoS dissolving their links with local councils and foregoing the concomitant funding and connections. They would then have to join forces-or compete for space-with the already existing radical lobbying groups who often struggle to gain support from local communities except among the already initiated. In short, the critique is not constructive because it suggests that CoS should adopt an entirely different set of organisational principles to those around which it has built an impressive national network over more than a decade.

I propose that the extent to which the CoS movement is effective resistance should be analysed against a framework which leaves open the possibility for constructive critique by taking as unalterable its positionality within the local council structure. That is to say, the problems identified with the movement should be, at least to some extent, comprehensible from within its existing confines. It is not my intention to morally defend the reluctance of the CoS to intervene at the front line of immigration politics where it is usually the unfunded and most marginalised organisations who lead battles against the UK state. Nor is it my intention to promote the moderate and soft tactics of CoS over and above the more radical forms of resistance enacted by organisations doing excellent work often under the radar. That notwithstanding, the fact remains that $\mathrm{CoS}$ is the most visible and most influential counter-weight to UK hostility. It is often the first encounter people have with pro-immigrant politics and the first port of call for ordinary people who are suddenly compelled to act compassionately for migrants. To illustrate, CoS Bristol reports there are 200 people per day offering help (Topping, 2015, p. 3). Due to their local council links, they are the primary organisation providing advice and training on issues of immigration to public service providers such as libraries, schools and museums. Critics recommending a total overhaul of their entire way of working miss an opportunity to shape this influential movement within its own terms. Therefore, I identify the need to assess the sanctuary movement using a framework which recognises that resistance can come in subtle hues and can also be implicated in the systems of power they seek to challenge. A counter-conduct approach is appropriate for this task.

Counter-conduct, introduced by Foucault in his 1978 lectures (Foucault, 2007a), describes activities which are on the soft end of resistance and come in mundane forms (Bulley, 2016, p. 243). The 'conduct' being countered refers to the 'processes implemented for conducting others' and is a way of conceptualising governmentality (Odysseos, Death, \& Malmvig, 2016, p. 153). Distinguishable from Foucault's other conceptualisations of power (discipline and sovereignty), conduire ('conduct') emphasises that power is not exercised coercively but is 'dependent on the freedom and activeness of individuals and groups of society' (Pyykkönen, 2015, p. 8). It follows, then, that conduct works as a 'self-limiting form of power, which is ever conscious of the counterproductive effects of imposition, and is therefore ever in pursuit of the "involvement," "co-ownership," and "willingness" of those it seeks to rule' (Malmvig, 2014, p. 295). While governmentality has been discussed in relation to immigration and asylum (Bigo, 2002; Darling, 2011; Fassin, 2011), its opposite number 'counter-conduct' —as a means of analysing resistance to governmental conduct-has been relatively understudied.

Counter-conducts employ a 'not necessarily spectacular or ground-breaking set of tactics' in their struggles against control (Bulley, 2016, p. 244). A counter-conducts approach is therefore apt to analyse 'much more diffuse and subdued forms of resistance' (Foucault, 2007a, p. 200). As argued by Death (2016, p. 217), 'practices which risk being rejected by a "resistance approach" for being insufficiently transformative can be re-evaluated through a counter-conducts approach.' 
Counter-conduct differs from resistance, disobedience, or revolt because it does not involve a 'complete refusal of the process of government' (Asl, 2018, p. 5). Rather, it expresses 'the will not to be governed thusly, like that, by these people, at this price' (Foucault, 2007b, p. 75). While resistance approaches find uncomfortable the notion that resistance and governmentality are mutually dependent and enhancing, counterconduct approaches recognise that particular operations of governmentality are not objected to, and may even be reinforced through counter-conduct. In other words, 'counter-conducts are forces and tendencies that emerge from within, but are marginal to, the form of conduct examined' (Bulley, 2016, p. 244). Against this background, counter-conduct has guided analysis of several opposition movements including Occupy (Rossdale \& Stierl, 2016), youth protests in Turkey (Çabuk Kaya \& Ural, 2018) and izikhothane protests in South Africa (Death, 2016), all of which reinforce or uphold some aspects of the forms of control they are opposing while countering others.

This Foucauldian approach has been formalised into heuristic models by Death among others (Death, 2010, 2016; Odysseos et al., 2016; Rosol, 2014). Death (2016, p. 211) argues that counter-conducts 'leads us to ask different questions' to those in resistance analyses. He proposes a focus on 'ways of being' which follows from the conceptualisation of conduct which is centred on the orchestration of selves:

The activity of conducting (conduire) [others]...the way in which one conducts oneself (se conduit), lets oneself be conducted (se laisse conduire)...and, finally, in which one behaves (se comporter) as an effect of a form of conduct (une conduit). (Foucault, 2007a, p. 193)

Counter-conduct, therefore, is a way of demonstrating 'we are not like that'; a subversion of the 'ways of being' which are hegemonized in conduire. Counter-conduct emerges as 'ethical self-formation' which works to 'alter modes of being in the world' (Death, 2016, p. 216).

In addition, as elaborated by Death (2016, p. 214), drawing on Moore (2013), a counter-conducts approach not only leads to inquiry about the ways of being conducted as the self, but also extends to the conducting of selves in relation to one another. As found in Foucault (Foucault, 2007a, p. 193), 'we can ascertain the multiple and related dimensions and domains of conduct as the conduct of individuals, relations between individuals, and as the way in which individuals conduct themselves.' In other words, a counter-conduct approach urges a questioning of which relational political subjectivities are being objected to and which new ones are emergent in their place. This can be achieved through asking questions such as: 'What new standards and practices of self-conduct are produced through protest?', 'What processes or technologies of intellectualised subject forma- tion can protests enable?' and 'What modes of selfhood and what processes of reflection on selfhood do they make possible?' (Death, 2016, pp. 215, 218).

Taking forward this model, counter-conduct has defined oppositional acts including local defiance against resource extraction in Brazil (Nepomuceno, Affonso, Fraser, \& Torres, 2019), parkour practices among young migrant men (de Martini Ugolotti \& Silk, 2018), MiddleEastern women's life writing (Asl, 2018) and amateur slam poets in the USA (Rivera, 2013). These studies focus on counter-conduct as the construction of 'alternative political subjectivities' (Çabuk Kaya \& Ural, 2018, p. 2010). They 'elucidate the political subjectivities emergent from the performance of dissent' (Nepomuceno et al., 2019, p. 124) against the forms of political subjectification imposed during governmental conduct. Following this lens and its applications, I provide a constructive analysis of where specifically, and against which models of governmental conduct, the sanctuary movement is (in)effective in counter-conducting the hostile environment.

\section{Countering Hostility through Storytelling}

The hostile environment conducts two pairs of dichotomous political subjectivities which are imposed on the non-citizen population. First, as Mulvey (2011, p. 1478) describes: 'Key to this process [of establishing hostility] was the attempt to create different conceptions of migrants according to "type".' In doing so, the UK state constructs 'ways of being' a migrant in the UK into two mutually exclusive categories into one of which, it implies, all immigrants must fall.

Most UK migration regimes have governed according to this kind of dichotomous subject formation yet the notion of what is good and what is bad changes with each new trend in governmentality. In the Blair era, for example, the 'good migrant' was defined as economically beneficial to UK society and the 'bad migrant' was a burden on the economy (Mulvey, 2011). What sets apart the Conservative hostile environment era from the economistic reasoning of New Labour, is the moralising tone it applies to subject formation. As Theresa May said in 2015: 'There are people who need our help, and there are people who are abusing our goodwill-and I know whose side I'm on. Humane for those who need our help, tough on those who abuse it' (The Independent, 2015). Here, the migrant political subjectivity is categorised into good and bad halves where the 'bad migrant' is construed, not only as an economic burden, but as morally corrupt and conspiratorial. Hostility is targeted at the economic migrant masquerading as a refugee, the benefit tourist, and the potential terrorist all of whom are here to 'abuse the goodwill' allegedly shown to them by the UK immigration system. On the other hand, the good migrant is construed as the morally virtuous refugee victim/hero who is fleeing a threat to their life and is fundamentally entitled to compassion. 
Within this rubric, the asylum seeker occupies a liminal space where it is not yet known into which of the two types of migrant they fall. Their status and the logic of the hostile environment implies that they must fall into one or the other. It is clear that this dichotomous narrative 'cannot speak for the heterogeneity of Britain's irregular migrant population' and uses 'a confused and unquantifiable construction' of irregularity (Price, 2014). Yet, it is these 'ways of being' which are conjured by this particular expression of control and the right of presence is reserved only for those who pass this moral test.

As other studies of counter-conduct demonstrate, 'the state uses "techniques of the self"' to create governable subjects yet counter-conduct gives rise to new identities and subjectivities' (Nepomuceno et al., 2019, p. 129). In many cases of successful counter-conduct, alternative subject positions are produced through acts of protest which expose conducted subjectivities as erroneous or mythical. Creative expression and storytelling, as Asl (2018) has shown in relation to Middle-Eastern women's writing, can be an avenue through which to perform novel political subjectivities: For instance, 'the struggle to be conducted differently...involves the negation of the prescribed modes of subjectivity that patriarchal governmentality forms and implants on the subjectivity of Arab women' (Asl, 2018, p. 10).

One key CoS activity, named the 'Arts Stream,' is participatory arts and public outreach whereby migrants are supported to craft and tell their stories to public audiences. Some cities have employed professional writers to deliver training workshops (Stickley, Hui, Stubley, Baker, \& Watson, 2018) and a recent project in Durham focused on storytelling through song-writing. Recently, a 'Raise my Voice' training workshop was held in Preston. Storytelling appears in CoS online literature as recommended practice for their training of public service providers and school visits. CoS therefore provides an opportunity to counter the morally good/bad subject formation of governmental conduct.

Evaluations of CoS storytelling practice have concluded they empower migrants, make them feel that their voice is finally being heard and positively affect the wellbeing of the individuals involved (Stickley et al., 2018). However, through these minor acts of protest, CoS have missed an opportunity to protest against and perform alternative modes of subject formation to those being constructed during governmental conduct. In the context of hostility towards all forms of irregular migrants, CoS focuses exclusively on the stories of those seeking asylum and, within that group, the asylum testimonies portrayed are highly homogenised to fit within the 'archetypal refugee' narrative described by Sandelind, Woods, and Nah (2018) as 'uncomplicatedly tragic.' Importantly, personal tragedy is used to demonstrate moral purity. In resources available (and linked to) on the CoS website and in CoS newsletter material, a total of 27 migrant stories draw on familiar tropes which emphasise the moral purity of asylum-seekers. The stories are taken from the
CoS newsletters and CoS website in the 'Resources' section. They link to specific stories from the BBC, Refugee Action, The Refugee Council, The Gulbenkian Foundation, Testimony Project and Al Jazeera.

To emphasise moral purity, $\operatorname{CoS}$ stories foreground stereotypically innocent identities. While the majority of asylum-seekers are single men aged 18+ (Eurostat, 2018), out of the 27 stories in the CoS resources, 12 were about children, 11 about women and only 4 about men, all of them with families. In addition, CoS resources commonly refer to the religious commitment of the protagonists. Sometimes their religious commitment is central to their asylum claim as in Rachel's story (Glynne, 2019) but on other occasions, religious indicators appear as arbitrary details. For example, 'A devout Catholic, Jenny believes what happened next was divine intervention' (Miller, 2019a, p. 11) and 'she stuffed a bag which now contained only her Bible with its black dog-eared leather cover' (Miller, 2019b, p. 10). Furthermore, stereotypically virtuous backgrounds of the asylum-seekers are foregrounded in the stories: 6 of the 11 women were employed in 'women's rights,' and one of the men was employed in a stereotypically virtuous line of work: human rights activism. From the 27 stories, 13 of them include stories of sexual abuse (suffered by almost all of the women and some of the children) and an additional 14 include stories of torture. The details are often presented as everyday occurrences to demonstrate their daily experience of victimhood: 'Marie went to the market in Kinshasa. She returned to an empty house and was sexually abused by police' (Miller, 2019b, p. 8).

While these kinds of stories are true for many people, other asylum-seekers and irregular migrants have far more complex stories to tell but are no less 'deserving' of the right of presence in the UK. For example, during their journeys, people may have made morally dubious decisions to cross borders illegally, pay traffickers, use false documents, or lie about their age. Many people, while living with a genuine and reasonable fear of persecution, have not experienced direct personal and/or sexual violence. Similarly, some people have made very ordinary journeys to the UK, on charter flights, or through over-staying student visas. None of these activities undermine what may be genuine claims of asylum, but they are silenced-edited out, or deselected-in CoS stories because they do not fit comfortably with the moral purity which has become so central to refugee 'credibility' and rightful presence (Sandelind in Sandelind et al., 2018). As observed by Woods (Sandelind et al., 2018), 'refugees are an incredibly diverse group' yet the stories told about refugees 'do not reflect that heterogeneity.' Instead they have contributed to a 'paradigmatic idea of what the refugee is' and in doing so have 'closed down the avenues for solidarity with all kinds of refugees' whose stories do not fit this narrow mould (Woods in Sandelind et al., 2018).

Furthermore, prospects for solidarity with other irregular migrants, not only those claiming refugee sta- 
tus, are also closed down by the absence of diversity in CoS migrant testimonies. Undocumented labour migrants who are not in the asylum system but whose lives have been made destitute by the hostile environment, are not made visible in $\operatorname{CoS}$ public outreach. As in the hostile environment, the right of presence is seen as dependent upon evidence of moral purity. This persistent re-telling of the classic refugee tale which portrays a very narrow picture of rightful presence does not unsettle the binary subjectivities set out in the hostile environment but upholds them.

A note in defence of CoS: The storytelling tropes in CoS literature do shift emphasis from the notion that most irregular migrants are morally dubious-as governmental conduct dictates-and instead suggest that the scale of the hostility is disproportionate to the numbers of migrants who are actually 'abusing the system.' While an average of only a third of asylum applications are deemed genuine by the UK state (Sturge, 2019, p. 6), CoS promotes the idea that nobody is here to 'cheat the system.' Furthermore, for CoS, the task of convincing a sceptical public is made easier with simple storytelling and thus the homogeneity of narratives serves the practical purpose of countering suspicion in the general public. However, these constitute short-term gains at the expense of long-term change that we know is made possible through committed counter-conduct. As explained by Çabuk Kaya and Ural (2018, p. 207), the notion of novelty in subject formation is key: 'the concept of counter-conduct points out the will to be governed differently as it seeks to cultivate an ethos of novelty.' It is clear in their study that counter-conduct has been successful when a 'new political subjectivity has been constructed' (Çabuk Kaya \& Ural, 2018, p. 209) through a 'novel way of being and acting.' The young protesters in their study in Turkey succeeded in constructing 'an alternative political subjectivity' to that which was imposed on them and thus qualified as successful counterconduct (Çabuk Kaya \& Ural, 2018, p. 210). Therefore, it is the production of novel-not adapted nor differently proportioned-political subjectivities which makes counter-conduct effective resistance. The storytelling so central to the outreach and therapeutic work of CoS, while having positive impact for those using the service, does not go as far as to produce novel political subjectivities since their definition of the 'good migrant' is just as narrow as the state's. A suggestion for CoS, therefore, is to follow the example of successful counter-conduct elsewhere and incorporate more nuance into the stories, include non-asylum-seeking migrants, and, importantly, make the right of presence independent of an unrealistically morally honourable lifestyle and identity.

\section{Countering Hostility through Refusing Judgement}

The second dichotomous set of political subjectivities constructed during governmental conduct are the judgmental citizen and the judged non-citizen. Crucially, the hostile environment dictates that so-called good and bad migrants can be exposed as such through one simple check of status: whether or not they are 'irregular.' The state has co-opted its citizens to take part in these judgemental checks based on the myth that, in doing so, they are performing the noble and highly 'citizenly' task of sifting the good from the bad. As Theresa May explained, 'the fewer people there are who wrongly claim asylum in Britain, the more generous we can be in helping the most vulnerable people' (The Independent, 2015). In seeking to recruit people into the judgemental process, Prime Minister David Cameron patently exhorted the British public: 'I want everyone in the country to help, including by reporting suspected illegal immigrants to our Border Agency through the Crimestoppers phone line or through the Border Agency website....Together we will reclaim our borders and send illegal immigrants home' (Travis, 2011). Civil society-here operating as an extension of the state-enact judgement in two ways: first, through the identification of migrant 'irregularity'; second, through deciding which category asylum-seekers fall into. The citizen is encouraged to play a role in both forms of judgemental procedure.

As noted by Pyykkönen (2015, p. 8), 'Foucault emphasizes that modern governmentality-and more specifically the procedures he names "the conduct of conduct" - are not exercised through coercive power and domination, but are dependent on the freedom and activeness of individuals and groups of society.' Therefore, the political subjectivities of judgemental citizen and the judged non-citizen are not fully 'conducted' until they are inculcated by the sections of the public. Public buyin of judgement has been substantial: The Home Office received around '2,100 public allegations per week in 2011' (Aliverti, 2015, p. 218). The wake of hostile environment policies saw increases in suspicion towards all people who are visibly 'non-native' as well as the 'institutionalisation of hostility towards migrants and migration more generally' (Mulvey, 2011, p. 1478). For example, following the recruitment of landlords into the judgement process, Lewis et al. (2017, p. 199) show clear evidence of 'discrimination by landlords towards non-British passport holders, and even those with foreign accents or names.' Furthermore, the context in 2019 including the rise of right-wing populism in general, and the deepening of anti-immigration rhetoric by Home Secretary Priti Patel and Prime Minister Boris Johnson can be traced, in part, to the foundations laid when the state asked its citizenry to consistently judge the migrant population.

CoS, owing to their being part of the local council structure, do not challenge the necessity of judgement by the state, and do not question the clarity of the state's judgement on 'irregularity.' Their seat at the table in the local council infrastructure, comes at the price of this acceptance. That notwithstanding, '[w]orking with a government doesn't imply either a subjection or a blanket acceptance' (Foucault, 2000, p.455). Through the practice of counter-conduct, 'one can work with and be in- 
transigent at the same time' (Foucault, 2000, p. 455). What remains within the power of the CoS movement is to resist being the judgemental citizen through enacting alternative non-judgemental political subjectivities and encouraging others to do the same.

Here, CoS is successful in enacting alternative political subjectivities. While they defer to the state to judge on irregularity, they refuse to perform judgement on asylum-seekers themselves. In place of judgement, comes neutrality and friendship with 'befriending' being one of the key actions of CoS. CoS facilitates such opportunities for non-judgemental friendship through 'Meet your Neighbour evenings' 'Buddy Projects,' day trips and even weekend excursions shared between asylumseekers and local people. The friendship-building activities have the dual purpose of 'tackling isolation and loneliness among refugees and educating and informing local communities to other cultures' (Molloy, 2019).

Davidson has shown the importance of friendship in cultivating counter-conduct since 'one conducts oneself in another way with friends, fabricating new ethical and political possibilities' (Davidson, 2011, p. 34). He argues that friendships both alter the relations between individuals and change one's relation to oneself. Taking this into their analysis of young Turkish people's resistance to the AKP government, Çabuk Kaya and Ural (2018, pp. 209-210) demonstrate how the LGBT factions within the movement were able to expose as derogatory many of the homophobic and transphobic slogans and works of graffiti being used by the other protesters. Their cultivation of new friendships among the diverse group of protesters allowed them to challenge the homophobic language deployed in the resistance movement. Working in a similar way, after a trip with CoS, one non-asylum seeker member reports 'Amazing memories, great times with incredible people, changing the world! Evening time together, making friends, thank you for the beautiful moments spent here' (City of Sanctuary, 2019, p. 17). Furthermore, instead of only accessing an already sympathetic section of the public, $\mathrm{CoS}$ befriending events reach those who express scepticism about asylum-seekers. For example, a CoS refugee meets a fisherman who 'thinks immigration should be controlled' (City of Sanctuary Newsletter, 2019) and a cub scout leader noted 'it's been good for our Cubs to meet refugees up close, being themselves, instead of just pictures on the news: to see that they're real people' (City of Sanctuary, 2019, p. 16). Similar to what was seen in the Turkish protest, in refusing to perform judgement, but instead facilitating non-hierarchical friendships, the judgemental citizen and judged non-citizen factions are dissolved as political subjectivities during CoS practice.

\section{Conclusions}

This article has two main contributions. First, an analytical contribution has been made to the debates on the social inclusion of immigrant non-citizens. Through reimagining resistance as counter-conduct, the article offers a novel understanding of how unspectacular forms of resistance to state exclusivity, when performed from within-as opposed to from outside of-governmental structures, are part of the broader picture of resistance. More specifically, this deepens our understanding of the various approaches to the question of who has rightful presence in the UK political community. By refusing to judge non-citizens, CoS compete with the state's conceptualisation of the political subjectivities on the inside and those of the outside of substantive citizenship. Yet, by using the archetypal victim/hero refugee story in their training and public outreach, CoS align with the state's conditions for rightful of presence. The CoS movement enacts successful counter-conduct for those who directly experience its work: those who are involved in befriending activities and the specific migrant population who access its services. However, in terms of challenging the wider narrative on rightful presence and moral purity, $\mathrm{CoS}$ is largely ineffective in resisting the hostile environment. Therefore, it can be said that CoS offers specific and personalized, but not general and society-wide, resistance to the hostile environment. Second, this article makes a normative contribution implied by the analytical findings. The article is written from the standpoint that the hostile environment should be resisted. To this end, through demonstrating how counter-conduct can be utilized as a form of soft resistance, the article offers a constructive critique of the CoS movement, and shows how its practice could be modified, rather than overhauled, to provide an effective resistance to hostility.

\section{Acknowledgments}

A version of this article was presented at the Vital Cities and Citizens conference at Erasmus University Rotterdam in November 2018. I am grateful to the panel organizer Helen Hintjens and to the fellow panellists and audience for their insightful comments. The initial motivation for this article arose in response to an exhibition and workshop series organised by London and Marrakech-based arts organisation Mint Works on the theme of 'Guests and Hosts.' As part of their programme, I hosted a discussion workshop and spoken word event in London in October 2018 and this article responds to the themes raised there. Many thanks to Florence Devereux, the Mint Works team and all of the workshop participants.

\section{Conflict of Interests}

The author declares no conflict of interests.

\section{References}

Aitkenhead, D. (2013, July 12). Sarah Teather: 'I'm angry there are no alternative voices on immigration.' The Guardian. Retrieved from https://www. 
theguardian.com/theguardian/2013/jul/12/sarahteather-angry-voices-immigration

Aliverti, A. (2015). Enlisting the public in the policing of immigration. The British Journal of Criminology, 55(2), 215-230.

Asl, M. P. (2018). Practices of counter-conduct as a mode of resistance in Middle East women's life writings. 3L: Language, Linguistics, Literature, 24(2). http:// dx.doi.org/10.17576/3L-2018-2402-15

Bagelman, J. (2013). Sanctuary: A politics of ease? Alternatives, 38(1), 49-62.

Barnett, C., \& Bhogal, I. (2009). City of sanctuary: A practical handbook with inspiring case studies. Ripon: Plug and Tap.

Bauder, H. (2016). Possibilities of urban belonging. Antipode, 48(2), 252-271.

Bauder, H. (2017). Sanctuary cities: Policies and practices in international perspective. International Migration, 55(2), 174-187.

Bauder, H., \& Gonzalez, D. A. (2018). Municipal responses to 'illegality': Urban sanctuary across national contexts. Social Inclusion, 6(1), 124-134.

BBC. (2019, January 14). Released asylum seeker returns to city. BBC News. Retrieved from https://www.bbc. com/news/uk-wales-46861727

Bigo, D. (2002). Security and immigration: Toward a critique of the governmentality of unease. Alternatives, 27(1), 63-92.

Bowling, B., \& Westenra, S. (2018). 'A really hostile environment': Adiaphorization, global policing and the crimmigration control system. Theoretical Criminology. Advance online publication. https://doi.org/10. $1177 / 1362480618774034$

Bulley, D. (2016). Occupy differently: Space, community and urban counter-conduct. Global Society, 30(2), 238-257.

Çabuk Kaya, N., \& Ural, H. (2018). The Gezi resistance of Turkey as young people's counter-conduct. In S. Pickard \& J. Bessant (Eds.), Young people regenerating politics in times of crises (pp. 199-215). Basingstoke: Palgrave.

City of Sanctuary. (2017). City of sanctuary charter 2017. Leeds: City of Sanctuary. Retrieved from https://cityofsanctuary.org/wp-content/uploads/ 2017/05/Charter_Final-updated-Oct-17-pdf-1.pdf

City of Sanctuary. (2019). City of sanctuary annual review 2018. Leeds: City of Sanctuary.

City of Sanctuary Newsletter. (2019). May Edition Newsletter. City of Sanctuary. Retrieved from https://us10.campaign-archive.com/?u=3914 d172a55a65237c1d2fe73\&id=54ca14e816

Critchley, J. C., \& Trembly, L. J. (2017). Historical review, current status and legal considerations regarding sanctuary cities. New Jersey Lawyer, 2017(June), 32-36.

Darling, J. (2011). Domopolitics, governmentality and the regulation of asylum accommodation. Political Geography, 30(5), 263-271.
Darling, J., Barnett, C., \& Eldridge, S. (2010). City of sanctuary: A UK initiative for hospitality. Forced Migration Review, 2010(34), 45-47.

Davidson, A. I. (2011). In praise of counter-conduct. History of the Human Sciences, 24(4), 25-41.

de Martini Ugolotti, N., \& Silk, M. (2018). Parkour, counter-conducts and the government of difference in post-industrial Turin. City, 22(5/6), 763-781.

Death, C. (2010). Counter-conducts: A Foucauldian analytics of protest. Social Movement Studies, 9(3), 235-251.

Death, C. (2016). Counter-conducts as a mode of resistance: Ways of "not being like that" in South Africa. Global Society, 30(2), 201-217.

Eurostat. (2018). Asylum statistics. European Commission. Retrieved from https://ec.europa.eu/eurostat/ statistics-explained/index.php/Asylum_statistics\# Age_and_gender_of_first-time_applicants

Fassin, D. (2011). Policing borders, producing boundaries: The governmentality of immigration in dark times. Annual Review of Anthropology, 40(1), 213-226.

Finch, T., \& Cherti, M. (2011). No easy options: Irregular migration to the UK. London: Institute for Public Policy Research. Retrieved from https://www.ippr.org/ files/images/media/files/publication/2011/05/ No\%20Easy\%200ptions\%20Apr2011_1837.pdf

Foucault, M. (2000). So, it is important to think (R. Hurley, Trans.)? In J. D. Faubion (Ed.), Power: Essential works of Foucault 1954-1984 (pp. 454-458). Retrieved from https://thenewpress.com/books/power

Foucault, M. (2007a). Security, territory, populationLectures at the Collège de France, 1977-78 (M. Senellart, Ed.; G. Burchell, Trans.). Basingstoke: Palgrave.

Foucault, M. (2007b). What is critique (L. Hochroth \& C. Porter, Trans.)? In S. Lotringer (Ed.), The politics of truth (pp. 41-81). Los Angeles, CA: Semiotexte.

Glynne, A. (Producer). (2019). Rachel's journey from a country in Eurasia [Animated documentary]. London: BBC. Retrieved from https://www.bbc.co.uk/ programmes/p00vdxp0

Grierson, A., Farrer, M., \& Sparrow, J. (2018, April 30). Sajid Javid disowns 'hostile environment' phrase in first outing as home secretary-As it happened. The Guardian. Retrieved from https://www. theguardian.com/politics/live/2018/apr/30/theresamay-new-home-secretary-amber-rudd-quitspolitics-live

Harvey, D. (2003). The right to the city. International Journal of Urban and Regional Research, 27(4), 939-941.

Hintjens, H., \& Pouri, A. (2014). Toward cities of safety and sanctuary. Peace Review, 26(2), 218-224.

House of Commons. (2015). The secretary of state for the Home Department (Mrs Theresa May). House of Commons Hansard. Retrieved from https:// hansard.parliament.uk/Commons/2015-1201/debates/15120141000002/ImmigrationBill? highlight=immigration\%20bill\#contribution15120151001264 
Immigration Act 2014, c. 22 (2014). Retrieved from http://www.legislation.gov.uk/ukpga/2014/22/ contents/enacted

Immigration Act 2016, c. 19 (2016). Retrieved from http://www.legislation.gov.uk/ukpga/2016/19/ contents/enacted

Immigration and Asylum Act 1999, c. 33 (1999). Retrieved from http://www.legislation.gov.uk/ukpga/ 1999/33/contents/enacted

Isin, E. F. (2013). Claiming European citizenship. In E. F. Isin \& M. Saward (Eds.), Enacting European citizenship (pp. 19-47). Cambridge: Cambridge University Press.

Kirkup, J. (2012, May 25). Theresa May interview: 'We're going to give illegal migrants a really hostile reception.' The Telegraph. Retrieved from https:// www.telegraph.co.uk/news/uknews/immigration/ 9291483/Theresa-May-interview-Were-going-togive-illegal-migrants-a-really-hostile-reception.html

Kmietowicz, Z. (2018). Doctors protest against 'hostile environment' immigration policy spreading to NHS. British Medical Journal, 2018(361). https://doi.org/ 10.1136/bmj.k1953

Lefebvre, H. (1968). Le droit à la ville [The right to the city]. Paris: Economica.

Lewis, H., Waite, L., \& Hodkinson, S. (2017). 'Hostile' UK immigration policy and asylum seekers' susceptibility to forced labour. In F. Vecchio \& A. Gerard (Eds.), Entrapping asylum seekers: Social, legal and economic precariousness (pp. 187-215). London: Palgrave Macmillan.

Malmvig, H. (2014). Free us from power: Governmentality, counter-conduct, and simulation in European democracy and reform promotion in the Arab World. International Political Sociology, 8(3), 293-310.

Menjívar, C. (2014). Immigration law beyond borders: Externalizing and internalizing border controls in an era of securitization. Annual Review of Law and Social Science, 10(1), 353-369. https://doi.org/10. 1146/annurev-lawsocsci-110413-030842

Miller, C. (2019a, June 16). A homeless refugee-activist's relentless fight for justice in DRC. Al Jazeera. Retrieved from https://www.aljazeera.com/indepth/ features/homeless-refugee-activist-relentless-fightjustice-drc-190613103230898.html

Miller, C. (2019b, June 20). From Kinshasa to Liverpool: A mother's painful journey to asylum. Al Jazeera. Retrieved from https://www.aljazeera.com/ indepth/features/kinshasa-liverpool-motherpainful-journey-asylum-190612085058050.html

Molloy, C. (2019). 'Meet your Neighbour'-Breaking down barriers between local communities and those seeking asylum. City of Sanctuary. Retrieved from https://arts.cityofsanctuary.org/2019/04/03/meetyour-neighbour-breaking-down-barriers-betweenlocal-communities-and-those-seeking-asylum

Moore, H. (2013, August 12). Protest politics and the ethical imagination. OpenDemocracy. Re- trieved from https://www.opendemocracy.net/en/ transformation/protest-politics-and-ethicalimagination

Mulvey, G. (2011). Immigration under new labour: Policy and effects. Journal of Ethnic and Migration Studies, 37(9), 1477-1493.

Nationality, Immigration and Asylum Act 2002, c. 41 (2002). Retrieved from http://www.legislation.gov. uk/ukpga/2002/41/contents/enacted

Nepomuceno, Í., Affonso, H., Fraser, J. A., \& Torres, M. (2019). Counter-conducts and the green grab: Forest peoples' resistance to industrial resource extraction in the Saracá-Taquera National Forest, Brazilian Amazonia. Global Environmental Change, 56, 124-133.

Odysseos, L., Death, C., \& Malmvig, H. (2016). Interrogating Michel Foucault's counter-conduct: Theorising the subjects and practices of resistance in global politics. Global Society, 30(2), 151-156.

Papademetriou, D. G. P. (2005, September 1). The global struggle with illegal migration: No end in sight. Migration Policy. Retrieved from https://www. migrationpolicy.org/article/global-struggle-illegalmigration-no-end-sight

Price, J. (2014). The hostile environment. In B. Anderson \& M. Keith (Eds.), Migration: A COMPAS anthology (n.p.). Oxford: COMPAS. Retrieved from http:// compasanthology.co.uk/wp-content/uploads/2014/ 02/Price_COMPASMigrationAnthology.pdf

Purcell, M. (2002). Excavating Lefebvre: The right to the city and its urban politics of the inhabitant. GeoJournal, 58(2/3), 99-108.

Pyykkönen, M. (2015). Liberalism, governmentality and counter-conduct; An introduction to Foucauldian analytics of liberal civil society notions. Foucault Studies, 2015(20), 8-35.

Rivera, T. (2013). You have to be what you're talking about: Youth poets, amateur counter-conduct, and Parrhesiastic value in the amateur youth poetry slam. Performance Research, 18(2), 114-123.

Rosol, M. (2014). On resistance in the post-political city: Conduct and counter-conduct in Vancouver. Space and Polity, 18(1), 70-84.

Rossdale, C., \& Stierl, M. (2016). Everything is dangerous: Conduct and counter-conduct in the occupy movement. Global Society, 30(2), 157-178.

Saadi, A., \& McKee, M. (2018). Hospitals as places of sanctuary. British Medical Journal, 2018(361). https://doi. org/10.1136/bmj.k2178

Salman, S. (2008, June 3). The Sheffield project dispelling misconceptions about asylum seekers and offering support. The Guardian. Retrieved from https://www.theguardian.com/society/2008/jun/ 04/asylum.support.sheffield

Sandelind, C., Woods, K., \& Nah, A. (2018, July 12). What does it mean to be in solidarity with refugees? [Audio file]. Retrieved from https://soundcloud.com/ user-223351495/what-does-it-mean-to-be-insolidarity-with-refugees 
Skinner, J., \& Salhab, A. (2019, May 17). How NHS staff are fighting back against the 'hostile environment.' OpenDemocracy. Retrieved from https:// www.opendemocracy.net/en/ournhs/how-nhs-staffare-fighting-back-against-the-hostile-environment

Squire, V. (2011). From community cohesion to mobile solidarities: The city of sanctuary network and the strangers into citizens campaign. Political Studies, 59(2), 290-307.

Squire, V., \& Darling, J. (2013). The "minor" politics of rightful presence: Justice and relationality in city of sanctuary. International Political Sociology, 7(1), 59-74.

Stickley, T., Hui, A., Stubley, M., Baker, F., \& Watson, M. C. (2018). "Write here, sanctuary" creative writing for refugees and people seeking asylum. Arts \& Health, 11(3), 1-18. https://doi.org/10.1080/ 17533015.2018.1494450

Sturge, G. (2019). Asylum statistics (Briefing Paper No. SN01403). London: House of Commons Library.

Swerts, T. (2017). Marching beyond borders: Noncitizen citizenship and transnational undocumented activism in Europe. In R. G. Gonzales \& N. Sigona, Within and beyond citizenship: Borders, membership and belonging (128-139). Abingdon: Taylor \& Francis.

Taylor, R. (2018). Impact of 'hostile environment' policy. London: House of Lords Library.

The Conservative Party. (2015). The Conservative Party manifesto 2015. London: Conservative Campaign Headquarters.

The Independent. (2015, October 6). Theresa May's speech to the Conservative Party Conference-In full. The Independent. Retrieved from http://www. independent.co.uk/news/uk/politics/theresa-may-sspeech-to-the-conservative-party-conference-in-fulla6681901.html

Topping, A. (2015, September 6). City of Sanctuary: Bristol rallies to help refugees as aid network swells. The Guardian. Retrieved from https://www. theguardian.com/world/2015/sep/06/city-ofsanctuary-bristol-rallies-to-help-refugees-as-aidnetwork-swells

Travis, A. (2011, October 10). David Cameron launches immigration crackdown. The Guardian. Retrieved from https://www.theguardian.com/uk/2011/oct/ 10/david-cameron-immigration-crackdown

Webber, F. (2004). Asylum-From deterrence to destitution. Race and Class, 45(3), 77-85.

Webber, F. (2018). How refugee and migrant solidarity groups are confronting the hostile environment. Institute of Race Relations. Retrieved from http:// www.irr.org.uk/news/how-refugee-and-migrantsolidarity-groups-are-confronting-the-hostileenvironment

Webber, F. (2019). On the creation of the UK's 'hostile environment.' Race \& Class, 60(4), 76-87.

Weisz, A. (2018). Preventative or performative? Assessing the role and intention of the UK's 'hostile environment' since 2010 (Unpublished Doctoral dissertation). Faculty of Graduate School of Arts and Sciences, Columbia University, New York, USA.

York, S. (2015). Revisiting removability in the hostile environment. Birkbeck Law Review, 3(2), 227-257.

Yuval-Davis, N., Wemyss, G., \& Cassidy, K. (2018). Everyday bordering, belonging and the reorientation of British immigration legislation. Sociology, 52(2), 228-244.

\section{About the Author}

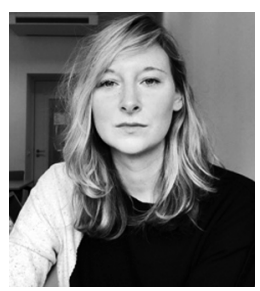

Cathy A. Wilcock is currently a Postdoctoral Researcher at the International Institute of Social Studies where she contributes to the Vital Cities and Citizens Programme within the Migration and Diversity stream. Here, she expands on her PhD which she received from The Global Development Institute at the University of Manchester through focusing on migration, citizenship and political subjectivities. Her main regional focus is on Sudan and the Sudanese diaspora in Europe, but she is also interested in the UK and EU asylum and immigration policy environments. 